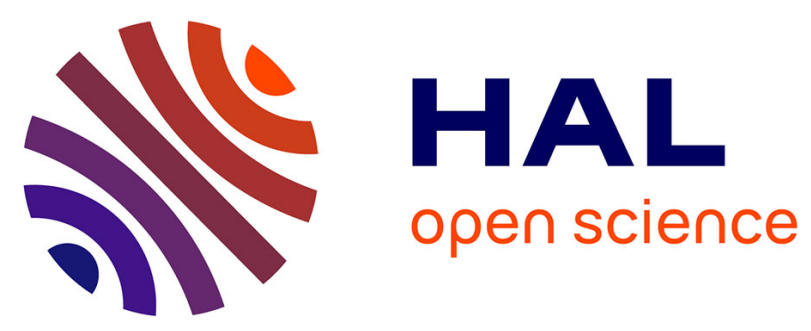

\title{
Photodermatitis from topical phenothiazines A case series
}

Claire Cariou, Catherine Droitcourt, Marie Noelle Osmont, Marie Claude

Marguery, Hervé Dutartre, Juliette Delaunay, Martine Avenel-Audran, Alain

Dupuy, Henri Adamski

\section{To cite this version:}

Claire Cariou, Catherine Droitcourt, Marie Noelle Osmont, Marie Claude Marguery, Hervé Dutartre, et al.. Photodermatitis from topical phenothiazines A case series. Contact Dermatitis, 2020, 83 (1), pp.19-24. 10.1111/cod.13509 . hal-02534804

\section{HAL Id: hal-02534804 https://hal-univ-rennes1.archives-ouvertes.fr/hal-02534804}

Submitted on 30 Apr 2020

HAL is a multi-disciplinary open access archive for the deposit and dissemination of scientific research documents, whether they are published or not. The documents may come from teaching and research institutions in France or abroad, or from public or private research centers.
L'archive ouverte pluridisciplinaire HAL, est destinée au dépôt et à la diffusion de documents scientifiques de niveau recherche, publiés ou non, émanant des établissements d'enseignement et de recherche français ou étrangers, des laboratoires publics ou privés. 


\section{Photodermatitis to topical phenothiazines: a case series}

Claire Cariou 1; Catherine Droitcourt 1,2; Marie Noelle Osmont 3; Marie Claude Marguery 4; Hervé Dutartre 5; Juliette Delaunay 6; Martine Avenel-Audran 6; Alain Dupuy 1,2; Henri Adamski 1.

\section{Affiliations:}

1 Department of Dermatology, CHU Pontchaillou, Rennes, France

2 UPRES-EA-7449 REPERES, Rennes, France

3 Centre of Pharmacovigilance, CHU Pontchaillou, Rennes, France

4 Paul Sabatier University and Department of Dermatology, Larrey Hospital, Toulouse, France

5 Department of Dermatology, CHU Hotel Dieu, Nantes, France

6 Department of Dermatology, Angers University Hospital, Angers, France

Conflicts of interest: None to declare. 


\section{Correspondence:}

Dr Henri Adamski, Department of Dermatology, CHU Pontchaillou, 2 rue Henri le Guilloux 35000 Rennes, France, Tel: 00332992843 49, Fax: 00332992841 00, E-mail : henri.adamski@chu-rennes.fr

\section{SUMMARY}

\section{Background:}

In Europe, contact photosensitivity to phenothiazines is known particularly in southern countries. Topical phenothiazines are widely used and sold over-the-counter for the treatment of mosquito bites and pruritus in France.

\section{Objective:}

To report a series of cases with photodermatitis to topical phenothiazines.

\section{Method:}

A retrospective study of cases of contact dermatitis to phenothiazines seen in French photodermatology centres was performed.

\section{Results:}

In all, 14 patients with the diagnosis of contact dermatitis to phenothiazines were included. These developed eczema on the application sites, and in 13 the eruption spread to photodistributed sites. Topical products containing isothipendyl were the most common cause of photodermatitis. One patient had photoaggravated eczema due to promethazine cream. All patients stopped using topical phenothiazines and were treated successfully with topical corticosteroids. One patient relapsed and developed persistent light eruption. In all of the 9 cases tested, photopatch testing to the topical phenothiazine used "as is" was positive. Isothipendyl, chlorproethazine and the excipients were not tested. Photopatch tests to chlorpromazine and promethazine were positive in 8/12 and 7/13 tested respectively. 


\section{Conclusion:}

Use of isothipendyl and promethazine as over-the-counter (or even prescribed) drugs needs to be limited due to severe reactions and sensitization to other phenothiazines that otherwise will have to be avoided.

\section{KEYWORDS}

Photoallergic contact dermatitis, eczema, topical phenothiazines, isothipendyl, CAS no. 48215-5, promethazine, CAS no. 60-87-7, photopatch test

\section{INTRODUCTION}

Photosensitivity is a potential adverse effect of systemic phenothiazines used as antipsychotic. Topical phenothiazines that have anti-histamine and muscle relaxant effects are widely prescribed and used as over-the-counter (OTC) antipruritic drugs. In Europe, topical photosensitivity to phenothiazines, notably to promethazine, is known ${ }^{1}$ particularly in southern countries..$^{2-4}$ Neuriplege ointment responsible for generalized and photoaggravated contact dermatitis due to active ingredient chlorproethazine ${ }^{5,6}$ was withdrawn from the French market in 2007. Three topical products containing phenothiazine, isothipendyl (Apaisyl gel, Sedermyl cream) and promethazine (Phenergan cream) are registered, and currently sold OTC for the treatment of mosquito bites and pruritus in France. Isothipendyl and promethazine are also sold in other European countries. The marketing authorization holders for these products are mainly located in Western Europe. The objective of the present study was to address the question of photosensitive dermatitis to topical phenothiazines since 2007.

\section{METHODS}


A retrospective study of cases of contact dermatitis to phenothiazines seen in French photodermatology centres from January 1, 2007 to October 31, 2019 was performed. Patients with a clinical diagnosis of contact dermatitis to a topical phenothiazine were included.

All members of the French Society of Photodermatology (SFPD) from 21 different French photodermatology units were contacted to contribute their eligible patients. A standardized questionnaire was sent to the SFPD members. The following information was collected from patient medical records: age, sex, medical history, current medications, clinical features, results of skin tests and photobiological exploration if performed.

\section{RESULTS}

\subsection{Patient characteristics}

A total of 14 patients were diagnosed with contact dermatitis to topical phenothiazine between January 2007 and October 2019. There were 6 female and 8 male patients, with a mean age at the time of diagnosis of 62 years (range: 27-88). The clinical characteristics of the patients are shown in Table 1 . Case 11 has been previously reported. ${ }^{7}$ Of the 14 patients, 3 had a history of photosensitive diseases. Case 3 had solar urticaria and cases 4 and 7 polymorphous light eruption. All developed eczema at the site of application of phenothiazine during sunny seasons. Distant sites were secondarily involved, including photodistributed areas, in 13 of 14 patients. The duration of eczema was longer than 3 months in 9/14, with recurrence in spring and summer (cases 3-5, 7 and 12). Topical product containing isothipendyl were the most common cause of photodermatitis (13/14). One patient used both isothipendyl gel and chlorproethazine ointment. Case 14 had photoaggravated eczema due to promethazine cream. Hospitalization was needed in cases 1, 2, 11 and 12. All patients stopped using topical phenothiazine and were treated successfully with a topical corticosteroid within 1 month. Relapse was observed in case 13 who developed persistent light eruption in the 2 years following contact photosensitization to isothipendyl, and needed to use photoprotective clothes and sunscreens. Other long-term medication was continued in all cases. 


\subsection{Photobiological investigations}

Phototesting was performed on the back of patients using a solar simulator (Dermolum UMUW, Müller Elektronik, Moosinning, Germany) equipped with a xenon light and metal halide lamp providing polychromatic irradiation (solar spectrum, 95\% UVA/5\% UVB) filtered with Schott WG 305 (cases 1, 3-5, 7-14) to evaluate minimal erythema dose (MED) at 24h after exposure. UVA MED and irradiation of patches were performed with UVA source: Waldmann (Reischtett, France) in cases 1, 3-5 and 12 (UV 182), case 6 (UV 801 KL) and cases 7-11 (UVA 700); and Dermolum (UM-UW, Müller Elektronik) with Schott WG 345 filter in cases 13 and 14. Photopatch tests included the SFPD standard series (29 photoallergens: antiseptics, cosmetics, plant products, promethazine, chlorpromazine and 8 UV filters $)^{6}$ with an extended list (11 other UV filters, ketoprofen, methylisothiazolinone, decyl glucoside and patients'own products). Patches were applied on the upper back in triplicate. One set was covered for $24 \mathrm{~h}$ and then irradiated with $5 \mathrm{~J} / \mathrm{cm}^{2}$ UVA and the other with polychromatic light (0.75 of the MED) whereas the third set was left in occlusion for 72h. Final readings were performed at $72 \mathrm{~h}$, according to International Contact Dermatitis Research Group guidelines.

Thirteen patients underwent photobiological explorations (Table 2). In all of the 9 cases tested, photopatch testing to the topical phenothiazine used "as is" was positive. Chlorproethazine, isothipendyl and the excipients were not tested because these substances had not been readily available. Photopatch tests to chlorpromazine $0.1 \%$ pet. and promethazine $0.1 \%$ pet. were positive in $8 / 12$ and $7 / 13$ tested, respectively. In one patient, the patch test to promethazine was positive without photoaggravation. Case 13 had also photosensitization to mequitazine administered for the treatment of eczema. In addition, past or associated relevant contact sensitivity (Myroxylon pereirae, fragrance mix, methylisothiazolinone) was found in 6 patients. The MED (polychromatic spectrum and/or UVA) was decreased in 4 cases. Two patients had repeated assessment of their MEDs which was normal 3 months later in case 11 . Concerning the patient with persistent light eruption 
(case 13), polychromatic MED returned to normal value while UVA MED was still decreased after one year of follow-up.

\section{DISCUSSION}

In most of our cases, contact photodermatitis was due to the products containing isothipendyl. One patient had no photobiological work-up. Nevertheless, the diagnosis of photocontact dermatitis to phenothiazines was made because eczema started on light-exposed areas following use of isothipendyl gel without relapse after discontinuation of the drug. In the literature, two cases of contact dermatitis to isothypendyl have been previously reported, ${ }^{7,8}$ including one of our patients. ${ }^{7}$ In France, benefit-risk assessment of isothipendyl products was initiated in 2017. Based on data from the French pharmacovigilance database and isothipendyl marketing authorization holders, 20 cases of severe cutaneous adverse reactions were identified (rash, urticaria, photodermatosis, eczema and purpura). The benefit-risk balance of isothipendyl was considered unfavorable, but this drug is still marketed to date. ${ }^{9}$ In our series, 4 patients were hospitalized. We observed one case of persistent light reaction due to isothipendyl as previously reported to chlorproethazine. ${ }^{5}$ This patient cross-photoreacted to another phenothiazine (mequitazine). In photoallergic reactions, cross-reactions between molecules belonging to the same chemical class such as phenothiazines may occur. ${ }^{5,7}$ In our series, some positive photopatch tests with a + reaction to isothipendyl gel and promethazine may represent just a phototoxic reaction. However, we consider this result as photoallergy owing to prior eczema in the patients. Positive photopatch tests to chlorpromazine and/or promethazine confirmed isothipendyl photoallergy in most of our patients using Apaisyl or Sedermyl. Such cross-sensitivity renders phentothiazines contra-indicated in patients with photocontact dermatitis from isothipendyl, as previously reported in cases with contact sensitization to chlorproethazine (Fig. 1). ${ }^{5}$ Moreau et al reported their experience among 20 patients and showed that isothipendyl is potentially phototoxic with UVA exposure, and induces more reactions than promethazine. ${ }^{10}$ These results were confirmed by photophysical analysis. The only difference in the chemical structure between isothipendyl and 
promethazine is the presence of nitrogen in isothipendyl, which may explain its higher photosensitizing potential. ${ }^{7}$ Contact photoallergy to isothypendyl was probably facilitated by the application of this topical drug on eczematous skin, promoting the penetration of the molecule and allergen presentation to immunocompetent cells. Regarding severe cutaneous drug reactions, 2 cases of toxic epidermal necrolysis after isothipendyl gel application has been reported. ${ }^{11}$

Topical promethazine is known to cause contact dermatitis and photosensitivity. ${ }^{1-4,12}$ In our series, one patient had photoaggravated eczema due to promethazine cream as previously published..$^{13}$ Goossens et al observed photoallergic reaction in 2 of 14 patients with contact allergy to topical promethazine among 12460 patch tests carried out. ${ }^{1}$ In addition to sensitization to promethazine, our patient had concomitant positive photoreaction to Myroxylon pereirae (balsam of Peru) and fragrance mix which could be explained by the presence of lavender essential oil as excipient ingredient in Phenergan cream. In our cases of photosensitive eczema to isothipendyl, co-sensitization to Myroxylon pereirae, fragrance mix and methylisothiazolinone was not due Apaisyl and Sedermyl in view of the absence of these allergens in isothipendyl products.

The present report confirms the need to keep chlorpromazine and promethazine in the photopatch test baseline series as a diagnostic marker of phenothiazine photoallergy according to the European Society for Contact Dermatitis and the European Society for Photodermatology recommendation. ${ }^{14}$ The photobiological explorations showed here that UVA is associated with phenothiazines photosensitivity, as in most drug-induced photosensitization. ${ }^{15}$ Some patients also reacted to UVB included in polychromatic spectrum irradiation.

In conclusion, we described a series of cases of contact photodermatitis to phenothiazines. In the most of the patients, eczema was due to products containing isothipendyl. Photocontact allergy to topical phenothiazines may be underestimated and lead to a delay in diagnosis, as in our series. Use of isothipendyl and promethazine needs to be limited due to severe reactions. 
In case of dermatitis on uncovered areas, it is recommended to focus the patient's history on topical products applied, and photopatch testing is recommended.

\section{REFERENCES}

1. Goossens A, Linsen G. Contact allergy to antihistamines is not common. Contact Dermatitis 1998; 39 (1): 38-39.

2. de la Cuadra-Oyanguren J, Pérez-Ferriols A, Lecha-Carrelero $\mathrm{M}$ et al. Results and assessment of photopatch testing in Spain: towards a new standard set of photoallergens. Actas Dermosifiliogr. 2007; 98 (2): 96-101.

3. Katsarou A, Makris M, Zarafonitis G, Lagogianni E, Gregoriou S, Kalogeromitros D. Photoallergic contact dermatitis: the 15-year experience of a tertiary reference center in a sunny Mediterranean city. Int J Immunopathol Pharmacol. 2008; 21 (3): 725-7.

4. Cardoso JC, Canelas MM, Gonçalo M, Figueiredo A. Photopatch testing with an extended series of photoallergens: a 5-year study. Contact Dermatitis. 2009; 60 (6): 325-329.

5. Barbaud A, Collet E, Martin S et al. Contact sensitization to chlorproethazine can induce persistent light reaction and cross-photoreactions to other phenothiazines. Contact Dermatitis. 2001; 44 (6): 373-374.

6. Leonard F, Adamski H, Bonnevalle A et al. Étude prospective multicentrique 19912001 de la batterie standard des photopatch-tests de la Société Française de Photodermatologie. Ann Dermatol Venereol. 2005; 132 (4): 313-20.

7. Bibas N, Sartor V, Bulai Livideanu C et al. Contact Photoallergy to isothipendyl chlorhydrate. Dermatology. 2012; 224 (4): 289-291.

8. Takashima A, Yoshikawa K. Contact allergy to isothipendyl. Contact Dermatitis.1983; 9 (5): 429-430.

9. ANSM, Agence nationale de sécurité du médicament et des produits de santé. Séance n5 Commission de suivi du rapport entre les bénéfices et les risques des produits de santé - Compte rendu de la réunion du 3 octobre 2017. Available at: 
https://www.ansm.sante.fr/content/download/115427/1460739/version/1/file/CR_Com mission+suivi_031017.pdf. Accessed February 10, 2020.

10. Moreau A, Dompmartin A, Dubreuil A, Leroy D. Phototoxic and photoprotective effects of topical isothipendyl. Photodermatol Photoimmunol Photomed. 1995; 11 (2): $50-54$.

11. Gravante G, Delogu D, Marianetti M, Trombetta M, Esposito G, Montone A. Toxic epidermal necrolysis and Steven Johnson syndrome: 11-years experience and outcome. Eur Rev Med Pharmacol Sci. 2007; 11 (2): 119-227.

12. Cantisani C, Ricci S, Grieco T et al. Topical promethazine side effects: our experience and review of the literature. Biomed Res Int. 2013; 2013:151509.

13. Arrue I, Rosales B, Ortiz de Frutos FJ, Vanaclocha F. Photoaggravated eczema due to promethazine cream. Actas Dermosifiliogr. 2007; 98 (10): 717-718.

14. Gonçalo M, Ferguson J, Bonevalle A et al. Photopatch testing: recommendations for a European photopatch test baseline series. Contact Dermatitis. 2013; 68 (4): 239-243.

15. Khandpur S, Porter RM, Boulton SJ, Anstey A. Drug-induced photosensitivity: new insights into pathomechanisms and clinical variation through basic and applied science. Br J Dermatol. 2017; 176 (4): 902-909.

\section{TABLES}

Table 1. Baseline and clinical characteristics of cases.

Table 2. Patch and phototest results.

\section{FIGURE}

Fig. 1. Phenothiazines chemical structures 
Table 1. Baseline and clinical characteristics of cases

\begin{tabular}{|c|c|c|c|c|c|c|c|}
\hline Case & $\begin{array}{l}\text { Age } \\
(\mathbf{y}) / \\
\text { Sex }\end{array}$ & $\begin{array}{l}\text { Past medical } \\
\text { history }\end{array}$ & $\begin{array}{c}\text { Long term } \\
\text { (over } 6 \\
\text { months) } \\
\text { concomittant } \\
\text { medication } \\
\end{array}$ & $\begin{array}{c}\text { Topical } \\
\text { phenothiazine } \\
\text { used : } \\
\text { Trade name (INN) }\end{array}$ & $\begin{array}{c}\text { Application } \\
\text { and period of } \\
\text { use }\end{array}$ & Location of eczema & $\begin{array}{l}\text { Symptoms duration } \\
\text { before diagnosis }\end{array}$ \\
\hline 1 & $68 / M$ & $\begin{array}{c}\text { Hypertension, } \\
\text { dyslipidemia }\end{array}$ & $\begin{array}{c}\text { Verapamil, } \\
\text { irbésartan, } \\
\text { hydro- } \\
\text { chlorothiazide, } \\
\text { atorvastatin }\end{array}$ & $\begin{array}{c}\text { Apaisyl gel } \\
\text { (isothipendyl) }\end{array}$ & $\begin{array}{c}\text { Discontinuous, } \\
8 \text { months }\end{array}$ & $\begin{array}{c}\text { Face, neck and upper } \\
\text { chest }\end{array}$ & 7 months \\
\hline 2 & 87/M & $\begin{array}{c}\text { Diabetes, } \\
\text { dyslipidemia, } \\
\text { hypertension }\end{array}$ & $\begin{array}{c}\text { glicazide, } \\
\text { simvastatin, } \\
\text { benazepril, } \\
\text { hydro- } \\
\text { chlorothiazide, } \\
\text { acétylsalicylate }\end{array}$ & $\begin{array}{c}\text { Apaisyl gel } \\
\text { (isothipendyl) }\end{array}$ & 15 days & $\begin{array}{l}\text { Face, neck, upper } \\
\text { chest, forearms } \\
\text { then abdomen and } \\
\text { thights }\end{array}$ & 7 days \\
\hline 3 & $43 / F$ & Solar urticaria & bilastine & $\begin{array}{c}\text { Apaisyl gel } \\
\text { (isothipendyl) }\end{array}$ & $\begin{array}{c}\text { Discontinuous, } \\
2 \text { years }\end{array}$ & $\begin{array}{c}\text { Face, chest, forearms } \\
\text { and dorsum of the } \\
\text { hands }\end{array}$ & 2 years \\
\hline & $27 / M$ & $\begin{array}{l}\text { Polymorphous } \\
\text { light eruption }\end{array}$ & $\begin{array}{c}\text { Hydroxy- } \\
\text { chloroquine }\end{array}$ & $\begin{array}{c}\text { Apaisyl gel } \\
\text { (isothipendyl) }\end{array}$ & $\begin{array}{c}\text { Discontinuous } \\
4 \text { years }\end{array}$ & $\begin{array}{c}\text { Face, neck and } \\
\text { dorsum of the hands }\end{array}$ & 4 years \\
\hline & $39 / F$ & Cholecystectomy & None & $\begin{array}{c}\text { Apaisyl gel } \\
\text { (isothipendyl) }\end{array}$ & $\begin{array}{l}\text { Discontinuous } \\
1 \text { year }\end{array}$ & Face and upper chest & 1 year \\
\hline 6 & $57 / F$ & Hypothyrodism & Levothyroxine & $\begin{array}{c}\text { Apaisyl gel } \\
\text { (isothipendyl) }\end{array}$ & 3 days & $\begin{array}{c}\text { Neck, shoulders, hand } \\
\text { back }\end{array}$ & 3 weeks \\
\hline 7 & $74 / M$ & $\begin{array}{l}\text { Polymorphous } \\
\text { light eruption }\end{array}$ & $\begin{array}{c}\text { Hydroxy- } \\
\text { chloroquine }\end{array}$ & $\begin{array}{c}\text { Apaisyl gel } \\
\text { (isothipendyl) }\end{array}$ & $\begin{array}{l}\text { Discontinuous } \\
3 \text { years }\end{array}$ & Face, neck, forearms & 3 years \\
\hline & $69 / \mathrm{M}$ & $\begin{array}{c}\text { Diabetes, } \\
\text { dyslipidemia, } \\
\text { hypertension, }\end{array}$ & $\begin{array}{l}\text { Metformin, } \\
\text { rosuvastatin, } \\
\text { perindopril, } \\
\text { diltiazem }\end{array}$ & $\begin{array}{c}\text { Apaisyl gel } \\
\text { (isothipendyl) }\end{array}$ & $\begin{array}{c}\text { Discontinuous } \\
5 \text { years }\end{array}$ & Left upper limb & 1 month \\
\hline 9 & $66 / M$ & None & None & $\begin{array}{c}\text { Apaisyl gel } \\
\text { (isothipendyl), } \\
\text { Neuriplege } \\
\text { ointment } \\
\text { (chlorproethazine) }\end{array}$ & 7 days & $\begin{array}{l}\text { Face, neck, foremars, } \\
\text { dorsum of the hands }\end{array}$ & 1 month \\
\hline & $68 / M$ & None & None & $\begin{array}{c}\text { Apaisyl gel } \\
\text { (isothipendyl) }\end{array}$ & $\begin{array}{l}\text { Discontinuous } \\
3 \text { months }\end{array}$ & $\begin{array}{l}\text { Thumbs, dorsum of } \\
\text { the hands, forearms, } \\
\text { neck and face then } \\
\text { trunk and lower } \\
\text { limbs }\end{array}$ & 6 months \\
\hline & $56 / \mathrm{F}$ & $\begin{array}{c}\text { Veinous } \\
\text { insufficiency of } \\
\text { legs }\end{array}$ & None & $\begin{array}{c}\text { Apaisyl gel } \\
\text { (isothipendyl) }\end{array}$ & $\begin{array}{l}\text { Discontinuous } \\
4 \text { months }\end{array}$ & $\begin{array}{c}\text { Face neck, forearms, } \\
\text { dorsum of the hands } \\
\text { then erythroderma }\end{array}$ & 4 months \\
\hline & $88 / F$ & $\begin{array}{c}\text { Dubreuilh } \\
\text { melanoma, } \\
\text { thyroidectomy }\end{array}$ & Levothyroxine & $\begin{array}{l}\text { Sedermyl cream } \\
\text { (isothipendyl) }\end{array}$ & $\begin{array}{l}\text { Discontinuous } \\
13 \text { months }\end{array}$ & $\begin{array}{l}\text { Face, forearms, } \\
\text { upper chest }\end{array}$ & 13 months \\
\hline & $53 / \mathbf{F}$ & None & None & $\begin{array}{l}\text { Sedermyl cream } \\
\text { (isothipendyl) }\end{array}$ & 1 day & $\begin{array}{l}\text { Face, dorsum of the } \\
\text { hands and feet }\end{array}$ & 4 months \\
\hline & $72 / \mathrm{M}$ & None & None & $\begin{array}{l}\text { Phenergan cream } \\
\text { (promethazine) }\end{array}$ & $\begin{array}{l}\text { Discontinuous } \\
1 \text { month }\end{array}$ & Face, neck and back & 1 month \\
\hline
\end{tabular}

Abbreviations. y: years. M: male. F: female. INN: International Non-Proprietary name. 
Table 2. Patch and phototest results

\begin{tabular}{|c|c|c|c|c|c|c|}
\hline Case & $\begin{array}{c}\text { Polychromatic } \\
\text { minimal } \\
\text { erythema dose } \\
\left(J / \mathbf{c m}^{2}\right)\end{array}$ & $\begin{array}{c}\text { UVA } \\
\text { minimal } \\
\text { erythema } \\
\text { dose } \\
\left(\mathbf{J} / \mathbf{c m}^{2}\right)\end{array}$ & $\begin{array}{c}\text { Topical } \\
\text { phenothiazine } \\
\text { used as is } \\
\text { NI/UVA/ } \\
\text { polychromatic } \\
\text { (day 3) }\end{array}$ & $\begin{array}{l}\text { Chlorpromazine } \\
\text { 0.1\% pet. } \\
\text { NI/UVA/ } \\
\text { polychromatic } \\
\text { (day 3) }\end{array}$ & $\begin{array}{l}\text { Promethazine } \\
\text { 0.1\% pet. } \\
\text { NI/UVA/ } \\
\text { polychromatic } \\
\text { (day 3) }\end{array}$ & $\begin{array}{c}\text { Other positive patch } \\
\text { tests } \\
\text { NI/UVA/polychromatic } \\
\text { (day 3) }\end{array}$ \\
\hline & $\begin{array}{l}\text { Decreased } \\
(<0.5, N>1)\end{array}$ & ND & $\begin{array}{l}\text { Apaisyl } \\
-/+++/ \text { ND }\end{array}$ & $-/+/ \mathbf{N D}$ & $-/+++/ \mathbf{N D}$ & $-/-/-$ \\
\hline & ND & ND & $\begin{array}{l}\text { Apaisyl } \\
\text { ND }\end{array}$ & ND & ND & ND \\
\hline & $\begin{array}{c}\text { Normal } \\
(1.25, N>1)\end{array}$ & ND & $\begin{array}{l}\text { Apaisyl } \\
-/++/ \mathbf{N D}\end{array}$ & -/-/ND & $-/+/ \mathbf{N D}$ & $-/-/-$ \\
\hline & $\begin{array}{c}\text { Normal } \\
(1.75, N>1)\end{array}$ & ND & $\begin{array}{l}\text { Apaisyl } \\
\text { ND }\end{array}$ & $-/+++/ \mathbf{N D}$ & $-/-/$ ND & $\begin{array}{l}\text { Methylisothiazolinone } \\
0.2 \% \text { aq. }+++/+++/ \mathrm{ND}\end{array}$ \\
\hline 5 & ND & ND & $\begin{array}{l}\text { Apaisyl } \\
\text { ND }\end{array}$ & $-/-/$ ND & $-/+/ \mathbf{N D}$ & $\begin{array}{c}\text { Myroxylon pereirae } 25 \% \\
\text { pet. } \\
+/+/ \mathrm{ND}\end{array}$ \\
\hline & ND & ND & $\begin{array}{c}\text { Apaisyl } \\
-/+++/ \mathbf{N D}\end{array}$ & ND & $-/++/ \mathbf{N D}$ & $-/-/ \mathbf{N D}$ \\
\hline & $\begin{array}{c}\text { Normal } \\
(0.42, N>0.4)\end{array}$ & $\begin{array}{c}\text { Decreased } \\
(<15)\end{array}$ & $\begin{array}{l}\text { Apaisyl } \\
-/+/+\end{array}$ & $-/-/-$ & $-/-/-$ & $-/-/-$ \\
\hline & $\begin{array}{c}\text { Normal } \\
(0.7, \mathrm{~N}>0.4)\end{array}$ & $\begin{array}{r}\text { Normal } \\
(>15)\end{array}$ & $\begin{array}{l}\text { Apaisyl } \\
-/+/+\end{array}$ & $-/-/-$ & $-/-/-$ & $\begin{array}{c}\text { Myroxylon pereirae } 25 \% \\
\text { pet. }+/+/+\end{array}$ \\
\hline & $\begin{array}{c}\text { Normal } \\
(\mathbf{1 . 5 5}, \mathrm{N}>\mathbf{0 . 4})\end{array}$ & $\begin{array}{c}\text { Normal } \\
(>15)\end{array}$ & $\begin{array}{l}\text { Neuriplege and } \\
\text { Apaisyl } \\
\text { ND }\end{array}$ & $-/+++/++$ & $-/-/-$ & $-/-/-$ \\
\hline & $\begin{array}{l}\text { Normal } \\
(1.88, N>0.4)\end{array}$ & $\begin{array}{c}\text { Normal } \\
(>15)\end{array}$ & $\begin{array}{c}\text { Apaisyl } \\
-/ / /+\end{array}$ & $-/+++/+++$ & $-/-/-$ & $-/-/-$ \\
\hline & $\begin{array}{l}\text { Decreased } \\
(0.05, N>0.4)\end{array}$ & $\begin{array}{c}\text { Decreased } \\
(<15)\end{array}$ & $\begin{array}{c}\text { Apaisyl } \\
-/+++/ \mathbf{N D}\end{array}$ & $-/+/-$ & $-/-/-$ & $-/-/-$ \\
\hline & $\begin{array}{r}\text { Decreased } \\
(<0.5, N>1)\end{array}$ & ND & $\begin{array}{l}\text { Sedermyl } \\
\text { ND }\end{array}$ & $-/++/ \mathbf{N D}$ & $-/++/ \mathbf{N D}$ & $\begin{array}{c}\text { Myroxylon pereirae } 25 \% \\
\text { pet. }+/+/ \text { ND }\end{array}$ \\
\hline & $\begin{array}{c}\text { Decreased } \\
(<0.5, N>1)\end{array}$ & $\begin{array}{c}\text { Decreased } \\
(<15)\end{array}$ & $\begin{array}{c}\text { Sedermyl } \\
+/++/++\end{array}$ & $-/++/-$ & $-/+++++$ & $\begin{array}{c}\text { Mequitazine }+/++/++ \\
\text { Fragrance mix 8\% pet. } \\
\text {-/+/- }\end{array}$ \\
\hline & $\begin{array}{l}\text { Normal } \\
(1.6, N>1)\end{array}$ & $\begin{array}{c}\text { Normal } \\
(>15)\end{array}$ & $\begin{array}{l}\text { Phenergan } \\
++/+++/+++\end{array}$ & $-/++/-$ & $++/++/++$ & $\begin{array}{c}\text { Myroxylon pereirae } 25 \% \\
\text { pet. }-/+/- \\
\text { Fragrance mix } 8 \% \text { pet. } \\
-/+/- \\
\end{array}$ \\
\hline
\end{tabular}

Abbreviations. N: normal value of polychromatic minimal erythema dose depending on center evaluation specified. NI: Nonirradiated. ND: not done.,,++++++ : positive reaction, -: negative reaction at 72 hours (day 3 ) according to ICDRG (International Contact Dermatitis Research Group). $\uparrow$ Case 2 declined photobiological explorations and did not relapse after 9 months of follow-up. $\$$ Mequitazine pet. (contents of Primalan ${ }^{\circledR}$ tablet). 

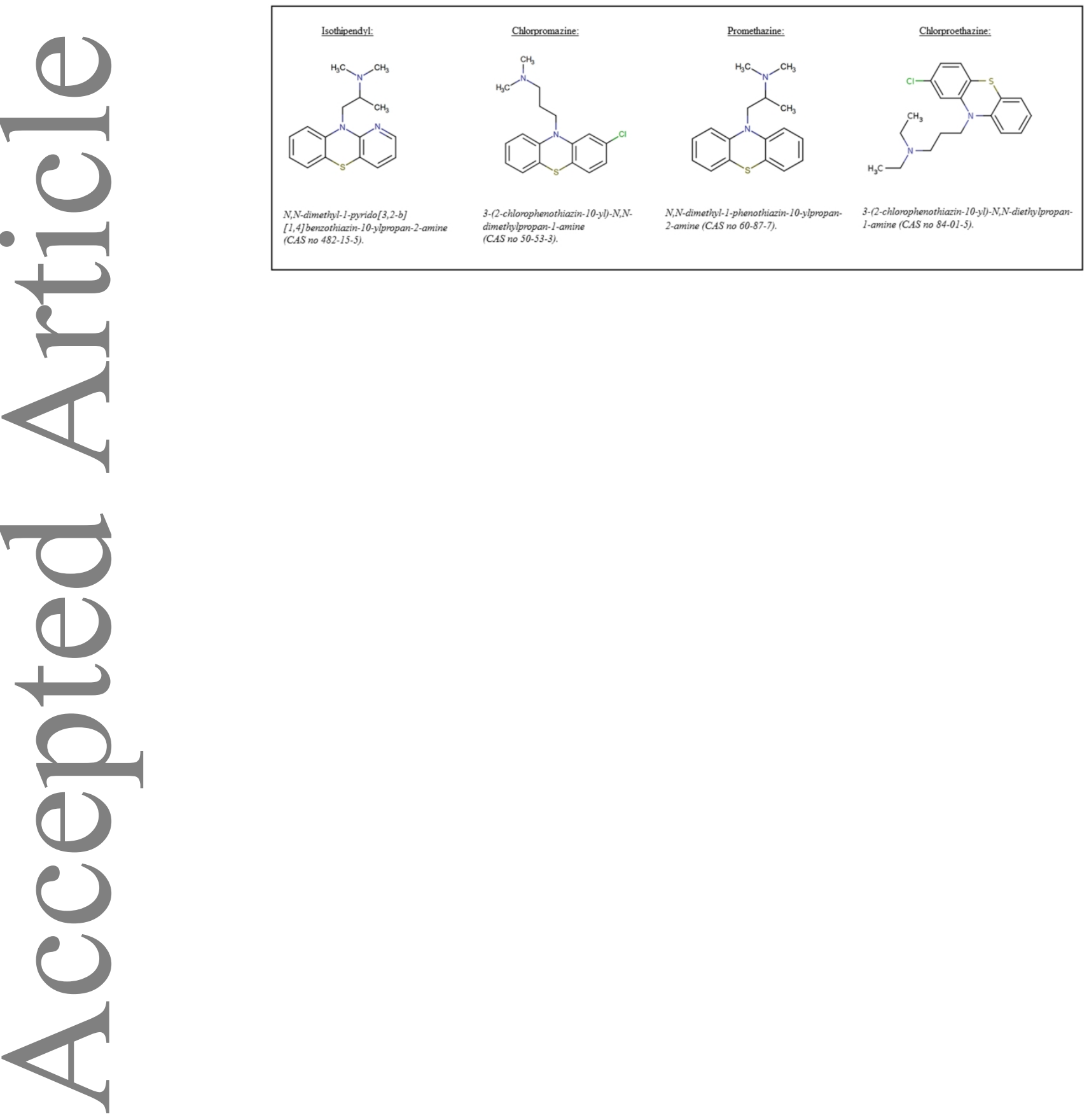